\title{
Validation method and proficiency test for the determination of free and hydrolysed formaldehyde
}

DOI: 10.35530/IT.071.03.1423

LUCIA OANA SECĂREANU

MIHAELA-CRISTINA LITE

ELENA PERDUM

CORNELIA-ELENA MITRAN

OVIDIU-GEORGE IORDACHE

Validation method and proficiency test for the determination of free and hydrolysed formaldehyde

Formaldehyde resins are usually used in the textile industry to prevent wrinkling, as well as for conservation of textile artifacts. The International Agency for Research on Cancer (IARC) classified formaldehyde as carcinogenic to humans. There are several regulations regarding the amount of formaldehyde found in textiles, for example Oeko-Tex Standard 100, REACH and European Ecolabel. In the present work, a spectrophotometric method for quantitative determination of free and hydrolyzed formaldehyde extracted through partial hydrolysis by using aqueous extraction was developed and validated. The method is in conformity with SR EN ISO 14184-1:2012 standard. The results of the validation parameters are $0.0117 \mathrm{mg} / \mathrm{l}$ for detection limit and $0.039 \mathrm{mg} / \mathrm{l}$ for quantification limit. The working field was proved to be linear in $0.15 \mu \mathrm{g} \mathrm{CH}$ parameter value is $89.80 \%$. Selectivity was determined in relation to acetic anhydride and the spectrophotometric method was proven to be selective for the quantitative determination of formaldehyde. Besides the validation method, a control diagram has been constructed by measuring a solution of known concentration 10 times. The selected concentrations are $0.16 \mathrm{mg} / \mathrm{l}$ and $0.75 \mathrm{mg} / \mathrm{l}$. These solutions are measured before the actual samples. To ensure the accuracy of the results, our laboratory participated to a proficiency test conducted by ASQUAL. The z-score obtained was 0.38 and the number of participating laboratories was 13.

Keywords: formaldehyde, textile, ecology, validation method, proficiency test

\section{Metodă de validare și teste interlaboratoare pentru determinarea formaldehidei libere și hidrolizate}

Rășinile pe bază de formaldehidă sunt, de obicei, utilizate în industria textilă pentru prevenirea șifonării materialelor și, de asemenea, pentru conservarea artefactelor textile. Agenţia Internaţională pentru Cercetarea Cancerului (IARC) a clasificat formaldehida drept carcinogenă pentru oameni. În prezent, există câteva organisme pentru regularizarea cantităţii de formaldehidă regăsită în materialele textile: Oeko-Tex Standard 100, REACH și European Ecolabel. În această lucrare a fost descrisă dezvoltarea și validarea unei metode spectrofotometrice pentru determinarea cantitativă a formaldehidei libere și hidrolizate extrasă prin hidroliză parţială, utilizând extracţia apoasă. Aceasta metodă este în conformitate cu standardul SR EN ISO 14184-1:2012. Rezultatele parametrilor de validare sunt 0,0117 mg/l pentru limita de detecţie și 0,039 mg/l pentru limita de cuantificare. Domeniul de lucru s-a dovedit a fi liniar în intervalul 0,15 $\mu \mathrm{g}$ $\mathrm{CH}_{2} \mathrm{O} / \mathrm{ml}-6,00 \mu \mathrm{g} \mathrm{CH} \mathrm{H}_{2} \mathrm{O} / \mathrm{ml}$, cu un coeficient de corelaţie de 0,999977. În plus, valoarea parametrului de recuperare este $89,80 \%$. Selectivitatea a fost determinată în raport cu anhidrida acetică, iar metoda spectrofotometrică s-a dovedit a fi selectivă, pentru determinarea cantitativă a formaldehidei. Pe lângă metoda de validare, a fost elaborată o diagramă de control, prin analiza unei soluţii de concentraţie cunoscută de 10 ori. Concentraţiile selectate sunt 0,16 mg/l și 0,75 mg/l. Aceste soluţii au fost analizate înaintea probelor propriu-zise. Pentru a asigura acurateţea rezultatelor, laboratorul nostru a participat la un test interlaboratoare condus de către ASQUAL. Scorul z obţinut a fost 0,38, iar numărul de laboratoare participante a fost 13.

Cuvinte cheie: formaldehidă, textile, ecologie, metodă de validare, teste interlaboratoare

\section{INTRODUCTION}

As the industry grows, more chemical products enter our life and come in contact with our skin or can be inhaled or ingested. One of these substances is formaldehyde [1]. Since its discovery, at the end of the nineteenth century, formaldehyde, also known as formalin, has been proven to possess antifungal and antimicrobial properties and, due to this reason, it has been also used as treatment for the conservation of textile artifacts [2-4]. Formaldehyde has been classified as carcinogenic to humans by IARC
(International Agency for Research on Cancer) [5]. Formaldehyde is a common precursor to more complex compounds and materials. The textile industry uses formaldehyde-based resins as finishing agents to make fabrics crease-resistant [6-7]. Formaldehyde is usually added to textile products to make them wrinkle-free, shrink proof, flame retardant and to maintain the durability of the printing and dyeing, or to improve the texture. Textile products and clothing containing formaldehyde will gradually release free formaldehyde [8]. Formaldehyde causes respiratory 
inflammation by inhalation and skin inflammation by skin contact and it also irritates the eyes.

Furthermore, prolonged exposure to formaldehyde may cause allergies and cancer. There are two standards for the determination of formaldehyde from textiles: one of them is ISO 14184-1:2012 "Determination of formaldehyde - part 1: free and hydrolyzed formaldehyde (water extraction method)" and the other one is ISO 14184-2:2012 "Determination of formaldehyde - part 2: released formaldehyde (vapor absorption method)". The amount of formaldehyde must not exceed 16 ppm [9-10]. In this paper, a method to determine the free and hydrolyzed formaldehyde from textiles is reported, the extraction being performed in distilled water. The method has been validated and the control method to improve the certainty of the obtained results has been established.

\section{EXPERIMENTAL}

\section{Validation method}

To validate this method, the following performance parameters have been determined: selectivity (specificity), limit of detection and limit of quantification, working range, analytical sensitivity, precision (repeatability and reproducibility) and recovery.

Selectivity (specificity)

Selectivity (specificity) is the ability of the method to measure the behaviour of the analyte in the presence of other impurities and compounds [11]. To evaluate this parameter, acetic anhydride (figure 1) and acetaldehyde (figure 2) have been measured trough spectrophotometric method in scan mode (350-480 $\mathrm{nm}$ range). The two solutions were prepared identically to the formaldehyde solutions, according to ISO 14184-1:2012. Moreover, the mixture of components that are mentioned in the working procedure and each component individually, including the analyte of interest have been analyzed. The concentrations are: $150 \mathrm{~g} / \mathrm{l}$ ammonium acetate, $3 \mathrm{ml} / \mathrm{l}$ acetic acid, $2 \mathrm{ml} / \mathrm{l}$ acetyl acetone, Nash reagent, $1.50 \mathrm{mg} / \mathrm{l}$ formaldehyde solution with Nash reagent and $6 \mathrm{mg} / \mathrm{l}$ formaldehyde solution with Nash reagent (Nash reagent is a solution obtained by the dissolution in distilled water of $75 \mathrm{~g}$ ammonium acetate, $1.5 \mathrm{ml}$ glacial acetic acid and $1 \mathrm{ml}$ acetylacetone in a dark $500 \mathrm{ml}$ volumetric flask).

Limit of detection (LOD) and limit of quantification (LOQ)

The limit of detection represents the lowest analyte concentration of a sample that can be detected with reasonable statistical certainty, but not necessarily quantified as an exact value under the established test conditions. In broad terms, the limit of detection is the lowest analyte concentration of a sample that can be safely distinguished from zero [12-13]. There are two types of detection limits: one for the instrument and one for the method. The LOD of the instrument is based on a sample analysis, measured using a spectrophotometer, without passing by the sample preparation. The LOD of the method is based on a sample analysis, measured with the spectrophotometer after it was passed through the entire working procedure. To determine the LOD of the method 10 blank samples have been prepared (Nash reagent with water $1: 1 \mathrm{v} / \mathrm{v}$ ) according to the working procedure and they were analyzed. LOD was calculated according to the formula: $L O D=0+3 \times S_{0}$. LOQ represents the lower concentration of analyte that can be measured with an acceptable performance. $L O Q$ was calculated using the formula: $L O Q=0+10 \times S_{0}$. Working range and method linearity

The working domain (the working concentration range) is the interval between the upper and the lower concentration of the analyte in the sample (including these concentrations) for which the procedure has been shown to have an adequate level of accuracy, precision and linearity [14]. For the determination of formaldehyde concentration, the working range is between $0.15 \mu \mathrm{g}\left(15 \mathrm{mg} / \mathrm{kg} \mathrm{CH} \mathrm{CH}_{2} \mathrm{O} / 1 \mathrm{~g}\right.$ of fab-

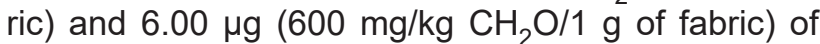
formaldehyde. To determine if the working range is suitable for the purpose of the method, 3 blank samples were submitted to UV-Vis spectrophotometer analysis and the 8 standard solutions $(0.1500 \mathrm{mg} / \mathrm{l}$, $0.30000 \mathrm{mg} / \mathrm{l}, 0.7500 \mathrm{mg} / \mathrm{l}, 1.5000 \mathrm{mg} / \mathrm{l}, 2.2500 \mathrm{mg} / \mathrm{l}$, $3.0000 \mathrm{mg} / \mathrm{l}, 4.5000 \mathrm{mg} / \mathrm{l}, 6.0000 \mathrm{mg} / \mathrm{l}$ ) were prepared according to SR EN ISO 14184-1:2012.

The linearity of a quantitative analytical method represents its ability to obtain results proportional to the concentration (quantity) of the analyte in the sample [13]. To evaluate the linearity, a calibration curve has been constructed, consisting of 8 concentration levels: 0.1275 (the concentration of the first solution is $15 \%$ lower than the one from the method), 0.3000 , $0.7500,1.5000,2.2500,3.0000,4.5000$ and 6.9000 $\mathrm{mg} / \mathrm{l}$ (the concentration of the last solution is $15 \%$ higher than the one from the method). The performance criteria are: the correlation coefficient to be 0.990000 , minimum and the curve to be linear.

Analytical sensitivity

The sensitivity of the analysis method represents the slope of the calibration curve or the regression coefficient [15]. To determine this parameter, a calibration curve in 8 points has been constructed.

Precision (repeatability and reproducibility)

The precision of the method is expressed by its repeatability and reproducibility. The description of repeatability is: the approximate results in a series of measurements from the same homogeneous sample under the same operating conditions, same analyst, same equipment, same laboratory and short operating time. The Repeatability Relative Standard Deviation (RSDR) ranges between $0.1-1.5 \%$ [13] To calculate the precision of the method a standard solution with concentrations of $2.5000 \mathrm{mg} / \mathrm{l}$ was submitted to ananlysis 10 times, in the same conditions. Reproducibility measures the dispersion of multiple measurement results for the same measurement, with the same method, in different laboratories, on identical samples, by different analysts using different equipment over a longer period of time. 


\section{Recovery}

Field recovery returns are accepted in $80-120 \%$ range for formaldehyde analysis using the spectrophotometric method. Three measurements were performed on an unfortified standard solution, on a fortified standard solution and on a fortified sample.

\section{Method robustness}

A RSD of up to $1 \%$ is acceptable for the determination of robustness. To evaluate the robustness of the method, three measurements of $2.25 \mathrm{mg} / \mathrm{l}$ formaldehyde solution after wavelength modification at 405 , 410 and $415 \mathrm{~nm}$ were performed.

\section{Proficiency test}

In order to confirm the precision and accuracy of the method, our laboratory participated at an inter-laboratory test organized by ASQUAL. A number of 13 laboratories took part at this study.

\section{Confirmation of the instrument performance}

To evaluate the quality of the equipment used for the analyis, a spectrum for a holmium oxide standard solution was recored.

\section{Uncertainty determination}

In order to calculate the uncertainty of the method it is necessary to take into account all the factors than can generate errors. Examples of such factors are: pipettes, volumetric flasks, analytical balance, the purity of the reagents used.

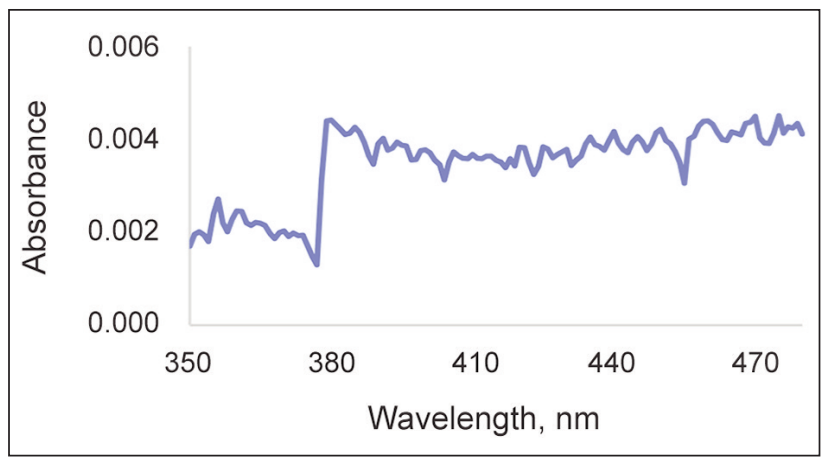

Fig. 1. UV-VIS spectrum for acetic anhydride

\section{RESULTS AND DISCUSSION}

\section{Selectivity (specificity)}

The overlapped UV-VIS spectra of the compounds used for this method, as well as the compounds with formaldehyde-like structure, such as acetaldehyde, are represented in figures 1,2 and 3 . These measurements were of great importance, as they have been used to prove that these substances do not interfere with the formaldehyde determination and that the method is selective.

\section{Limit of detection (LOD) and limit of quantification (LOQ)}

The values of LOD and LOQ are presented in table 1. These values indicate the suitability of the developed method for detection and quantification of formaldehyde at low levels.

\section{Working range and method linearity}

The data has been listed in table 2 . The values of the analyzed samples are very close to the known concentrations and the correlation coefficient is 0.99996 , therefore the chosen working range is suitable for the determination of formaldehyde in a concentration range between $0.15 \mathrm{mg} / \mathrm{l}-6.0 \mathrm{mg} / \mathrm{l}$.

By performing the calibration curve, a correlation coefficient of 0.999977 was obtained, which demonstrates excellent linearity in the $0.15 \mathrm{mg} / \mathrm{l}-6.00 \mathrm{mg} / \mathrm{l}$ concentration range, corresponding to $15 \mathrm{mg} / \mathrm{Kg}$ $600 \mathrm{mg} / \mathrm{Kg} \mathrm{CH} \mathrm{CH}_{2} \mathrm{O} / \mathrm{g}$ of fabric. The data is listed in table 3.

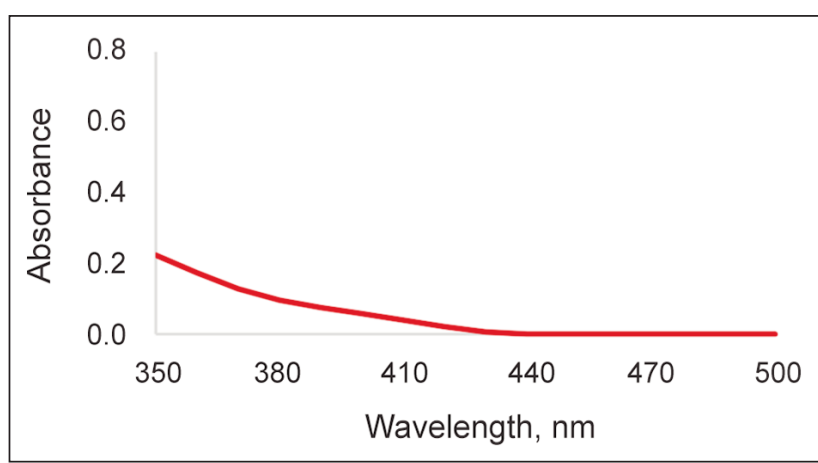

Fig. 2. UV-VIS spectrum for acetaldehyde

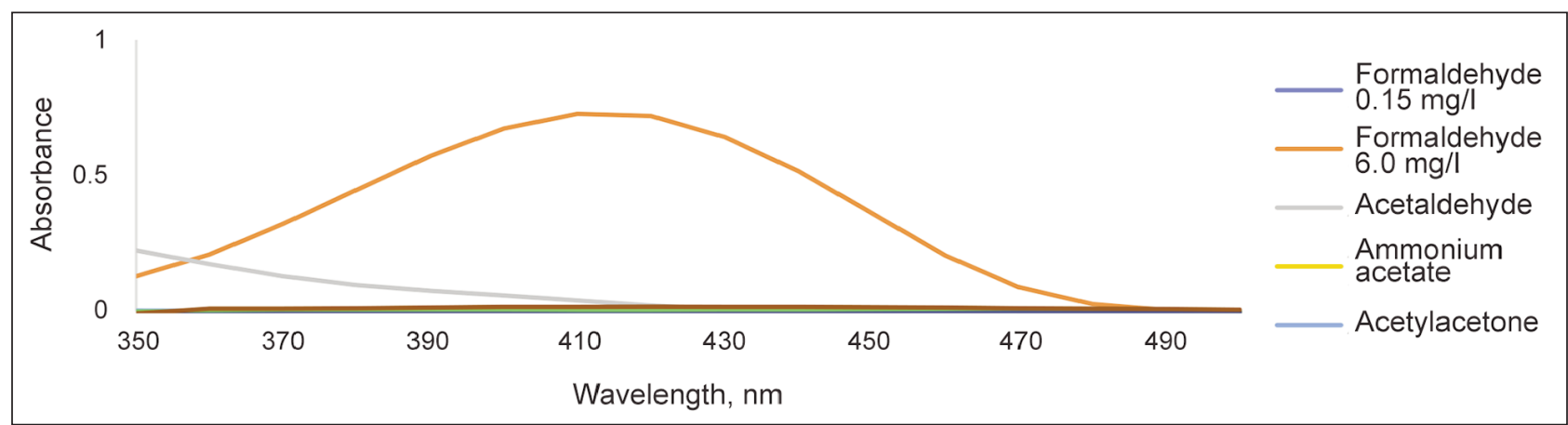

Fig. 3. Overlapped UV-VIS spectra of the compounds used for the current method, as well as the compounds with formaldehyde-like structure (acetaldehyde) 


\begin{tabular}{|c|c|c|c|c|c|c|c|c|c|c|}
\hline \multicolumn{11}{|c|}{ RESULTS FOR LOD AND LOQ MEASUREMENTS } \\
\hline $\begin{array}{c}\text { Blank - theoretical } \\
\text { concentration } 0(\mathrm{mg} / \mathrm{l})\end{array}$ & 1 & 2 & 3 & 4 & 5 & 6 & 7 & 8 & 9 & 10 \\
\hline Mean values $(\mathrm{mg} / \mathrm{l})$ & 0.0768 & 0.0554 & 0.0415 & 0.0480 & 0.0627 & 0.0558 & 0.0499 & 0.0807 & 0.0597 & 0.0656 \\
\hline Standard deviation $=\mathrm{S}_{0}$ & \multicolumn{10}{|c|}{0.0039} \\
\hline $\operatorname{LOD}\left(3 \times \mathrm{S}_{0}\right)$ & \multicolumn{10}{|c|}{0.0117} \\
\hline $\mathrm{LOQ}\left(10 \times \mathrm{S}_{0}\right)$ & \multicolumn{10}{|c|}{0.0390} \\
\hline
\end{tabular}

\begin{tabular}{|c|c|c|c|c|c|c|}
\hline \multicolumn{7}{|c|}{ CONCENTRATION VALUES CORRESPONDING TO THE 8 STANDARD SOLUTIONS } \\
\hline $\begin{array}{c}\text { Known } \\
\text { concentrations } x_{i} \\
(\mathrm{mg} / \mathrm{l})\end{array}$ & $\begin{array}{c}y_{i} \text { for the read } \\
\text { concentrations } \\
(\mathrm{mg} / \mathrm{l})\end{array}$ & $\begin{array}{c}\overline{x i} \\
(m g / l)\end{array}$ & $\begin{array}{c}\overline{y i} \\
(\mathrm{mg} / \mathrm{l})\end{array}$ & b slope & a intercept & $\begin{array}{c}\text { Pearson } \\
\text { coefficient } \rho\end{array}$ \\
\hline $\begin{array}{c}0.00 \\
\text { (blank sample) }\end{array}$ & 0.0348 & \multirow{9}{*}{2.0500} & \multirow{9}{*}{2.0524} & \multirow{9}{*}{0.9989} & \multirow{9}{*}{0.0047} & \multirow{9}{*}{1.0000} \\
\hline 0.1500 & 0.1587 & & & & & \\
\hline 0.3000 & 0.3072 & & & & & \\
\hline 0.7500 & 0.7457 & & & & & \\
\hline 1.5000 & 1.4768 & & & & & \\
\hline 2.2500 & 2.2367 & & & & & \\
\hline 3.0000 & 2.9856 & & & & & \\
\hline 4.5000 & 4.5302 & & & & & \\
\hline 6.0000 & 5.9963 & & & & & \\
\hline
\end{tabular}

\begin{tabular}{|c|c|c|c|}
\hline \multicolumn{3}{|c|}{ CONCENTRATION VALUES CORRESPONDING TO THE CALIBRATION CURVE } \\
\hline Level of concentration & Theoretical value & Measured value & Correlation coefficient $\mathbf{R}^{\mathbf{2}}$ \\
\hline 1 & 0.1275 & 0.1412 & \\
\hline 2 & 0.3000 & 0.2931 & \multirow{2}{*}{0.999977} \\
\hline 3 & 0.7500 & 0.7368 & \\
\hline 4 & 1.5000 & 1.4902 & \\
\hline 5 & 2.2500 & 2.2709 & \\
\hline 6 & 3.0000 & 2.9841 & \\
\hline 8 & 4.5000 & 4.5216 & \\
\hline
\end{tabular}

\section{Analytical}

\section{sensitivity}

The values of the obtained concentrations according to the measured absorbance of the solutions are listed in table 4. Based on these values, the method has been proven to have analytical sensitivity for the determination of formaldehyde.

\begin{tabular}{|c|c|c|c|c|c|c|}
\hline \multicolumn{7}{|c|}{ CONCENTRATION VALUES CORRESPONDING TO THE CALIBRATION CURVE } \\
\hline \multirow{2}{*}{$\begin{array}{c}\text { Specified } \\
\text { (mg/l) }\end{array}$} & \multirow{2}{*}{$\begin{array}{c}\text { Calculated } \\
(\mathrm{mg} / \mathrm{l})\end{array}$} & \multirow{2}{*}{$\begin{array}{c}\text { Residual } \\
\text { (mg/l) }\end{array}$} & \multicolumn{2}{|c|}{$\begin{array}{l}\text { Calibration } \\
\text { coefficient }\end{array}$} & \multirow{2}{*}{$\begin{array}{l}\text { Specified } \\
\text { correlation } \\
\text { coefficient }\end{array}$} & \multirow{2}{*}{$\begin{array}{l}\text { Calculated } \\
\text { correlation } \\
\text { coefficient }\end{array}$} \\
\hline & & & a & b & & \\
\hline 0.1500 & 0.1613 & -0.0113 & \multirow{8}{*}{-0.0046} & \multirow{8}{*}{-0.1395} & \multirow{8}{*}{0.9800} & \multirow{8}{*}{0.9999} \\
\hline 0.3000 & 0.3068 & -0.0068 & & & & \\
\hline 0.7500 & 0.7322 & 0.0178 & & & & \\
\hline 1.5000 & 1.4923 & 0.0077 & & & & \\
\hline 2.2500 & 2.2683 & -0.0183 & & & & \\
\hline 3.0000 & 2.9820 & 0.0180 & & & & \\
\hline 4.5000 & 4.5053 & -0.0053 & & & & \\
\hline 6.0000 & 6.0016 & -0.0016 & & & & \\
\hline
\end{tabular}




\section{Precision (repeatability and reproducibility)}

The results are presented in table 5 .

The RSDR values will be maximum 35\% (table 6).

\section{Recovery}

For the measurements performed on the unfortified standard solution, the average value obtained was 0.2986 , for the fortified standard solution the average value obtained was 2.3788 and for the fortified sample the average value obtained was 1.2174 . $\mathrm{R} \%=$
$100 \times \mathrm{c}^{\prime} / \mathrm{c} 3$ - were c3' is the theoretical concentration of the fortified sample and c3 - the average of the read fortified concentrations. The recovery is $\mathrm{R} \%=89.80 \%$, which is in the acceped range, proving that the method is suitable for the determination of formaldehyde.

\section{Method robustness}

The effect of each modification of the working conditions on the measurement results is represented in table 7 .

Table 5

\begin{tabular}{|c|c|c|c|c|c|c|}
\hline \multicolumn{7}{|c|}{ RESULTS FOR REPEATABILITY CALCULATION } \\
\hline $\begin{array}{c}\text { Theoretical } \\
\text { concentration } \\
\text { (mg/l) }\end{array}$ & $\begin{array}{c}\text { Read } \\
\text { concentration } \\
\text { (mg/l) }\end{array}$ & $\begin{array}{c}\text { Average } \\
\text { concentration } \\
\text { (mg/l) }\end{array}$ & $\begin{array}{c}\text { Repeatability } \\
\text { standard } \\
\text { deviation Sr } \\
\text { (mg/l) }\end{array}$ & $\begin{array}{c}\text { Repeatability } \\
\text { limit } r \\
(\mathrm{mg} / \mathrm{l}) \\
r=2.8 \mathrm{Sr}\end{array}$ & $\begin{array}{c}\text { Repeatability } \\
\text { relative standard } \\
\text { deviation }(\%) \\
\text { RSDr }=100 \times(\mathrm{Sr} / \mathbf{x})\end{array}$ & $\begin{array}{c}\text { Reproducibility } \\
\text { limit } \\
R=1.6 \times r \\
(\mathrm{mg} / \mathrm{l})\end{array}$ \\
\hline \multirow{10}{*}{2.5000} & 2.2018 & \multirow{10}{*}{2.2075} & \multirow{10}{*}{0.0025} & \multirow{10}{*}{0.0069} & \multirow{10}{*}{0.1100} & \multirow{10}{*}{0.0110} \\
\hline & 2.2065 & & & & & \\
\hline & 2.2057 & & & & & \\
\hline & 2.2063 & & & & & \\
\hline & 2.2082 & & & & & \\
\hline & 2.2092 & & & & & \\
\hline & 2.2090 & & & & & \\
\hline & 2.2090 & & & & & \\
\hline & 2.2092 & & & & & \\
\hline & 2.2098 & & & & & \\
\hline
\end{tabular}

Table 6

\begin{tabular}{|c|c|c|c|c|c|}
\hline \multicolumn{6}{|c|}{ RESULTS FOR REPRODUCIBILITY CALCULATION } \\
\hline $\begin{array}{l}\text { Theoretical } \\
\text { concentration } \\
\text { (mg/l) }\end{array}$ & $\begin{array}{c}\text { Average } \\
\text { concentration } \\
\text { (mg/l) }\end{array}$ & $\begin{array}{c}\text { Reproducibility } \\
\text { standard deviation } \\
\text { SR (mg/l) }\end{array}$ & $\begin{array}{l}\text { Reproducibility } \\
\text { limit } r \text { (mg/l) } \\
r=2.8 \mathrm{SR}\end{array}$ & $\begin{array}{l}\text { Reproducibility relative } \\
\text { standard deviation }(\%) \\
\text { RSDR }=100 \times(\mathrm{SR} / \mathrm{x})\end{array}$ & $\begin{array}{l}\text { Reproducibility } \\
\text { limit } R=1.6 \times r \\
(\mathrm{mg} / \mathrm{l})\end{array}$ \\
\hline 3 (First analyst) & \multirow{2}{*}{3.0489} & \multirow{2}{*}{0.0175} & \multirow{2}{*}{0.0489} & \multirow{2}{*}{0.0790} & \multirow{2}{*}{0.5735} \\
\hline 3 (Second analyst) & & & & & \\
\hline
\end{tabular}

Table 7

\begin{tabular}{|c|c|c|c|}
\hline \multicolumn{4}{|c|}{ RESULTS FOR ROBUSTNESS AFTER CHANGING THE WAVELENGTH VALUE } \\
\hline $\begin{array}{l}\text { Wavelength } \\
\quad(\mathrm{nm})\end{array}$ & $\begin{array}{l}\text { Formaldehyde standard } \\
\text { solution quantity (mg/l) }\end{array}$ & $\begin{array}{c}\text { Standard } \\
\text { deviation s }\end{array}$ & $\begin{array}{l}\text { Formaldehyde quantity detected }(\mathrm{mg} / \mathrm{l}) \\
\qquad \mathrm{RSD}=\mathrm{s} / \text { Xmedium }\end{array}$ \\
\hline \multirow{4}{*}{405} & \multirow{4}{*}{2.25} & \multirow{4}{*}{0.0017} & 2.2605 \\
\hline & & & 2.2625 Xmedium $=2.2619$ \\
\hline & & & 2.2627 \\
\hline & & & $2.2619 \mathrm{mg} / \mathrm{l} \pm 0.0761 \%$ formaldehyde \\
\hline \multirow{4}{*}{410} & \multirow{4}{*}{2.25} & \multirow{4}{*}{0.0015} & 2.2583 \\
\hline & & & 2.2599 Xmedium $=2.2595$ \\
\hline & & & 2.2603 \\
\hline & & & $2.2664 \mathrm{mg} / \mathrm{l} \pm 0.0662 \%$ formaldehyde \\
\hline \multirow{4}{*}{415} & \multirow{4}{*}{2.25} & \multirow{4}{*}{0.0015} & 2.2667 \\
\hline & & & 2.2673 Xmedium $=2.2664$ \\
\hline & & & 2.2652 \\
\hline & & & $2.2664 \mathrm{mg} / \mathrm{l} \pm 0.0675 \%$ formaldehyde \\
\hline
\end{tabular}




\section{Proficiency test}

The performance of the laboratory was evaluated according to "z-scores":

- $|z| \leq 2$ : result: correct (color code: green);

- $2<|z| \leq 3$ : result: questionable (warning signal color code: orange);

- $|z|>3$ : result: not satisfactory (action signal - color code: red).

The comparative results for the z-score obtained have been represented in figure 4 . The concentration values $(\mathrm{mg} / \mathrm{kg})$ attained by each laboratory have been presented in figure 5 . The leter $O$ was assigned to our laboratory and the $z$ score obtained was -0.38 .
Confirmation of the instrument performance

An example of the holmium oxide verification is shown in table 8.

The difference between the theoretical values and the measured values is less than $1 \mathrm{~nm}$, which is an indicator of the proper functioning of the equipment. Also, before each set of samples, 2 solutions from the calibration curve $(0.1600 \mathrm{mg} / \mathrm{l}$ and $0.7500 \mathrm{mg} / \mathrm{l})$ were analyzed. The values must range between the values from table 9 .

\section{Uncertainty determination}

The calculated value of the uncertainty for this method is $8.7 \%$.

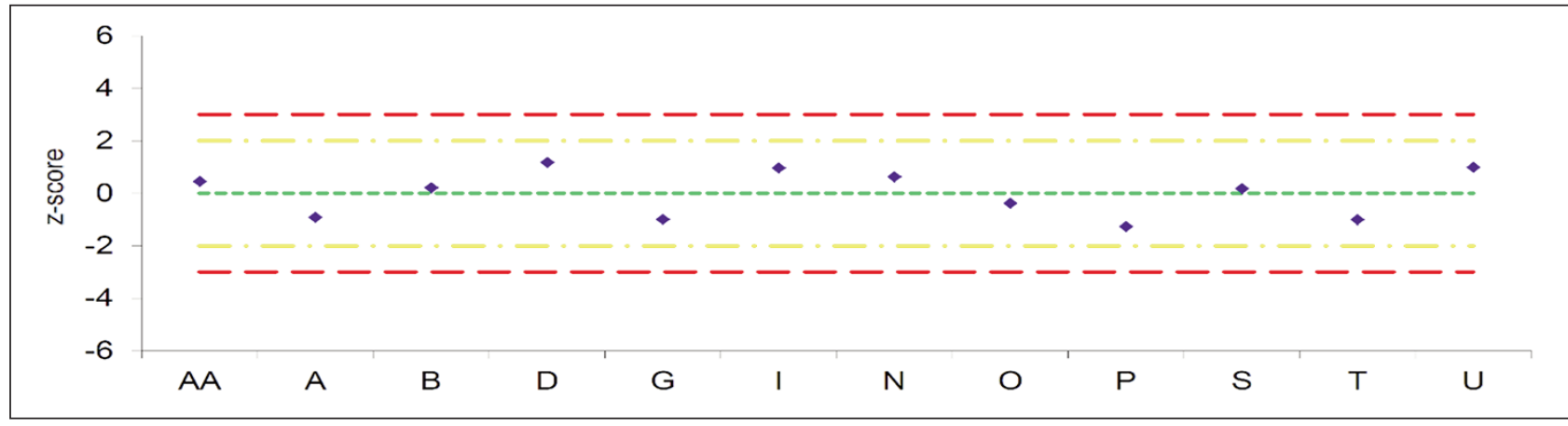

Fig. 4. Z-score value for each laboratory

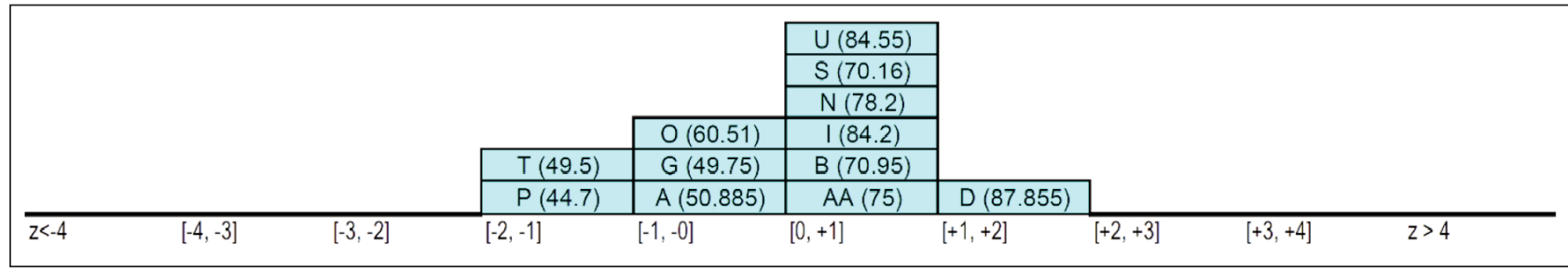

Fig. 5. Concentration in $\mathrm{mg} / \mathrm{kg}$ and $\mathrm{z}$-score for each laboratory

Table 8

\begin{tabular}{|c|c|c|c|c|c|c|c|c|c|c|c|c|c|c|c|}
\hline \multicolumn{16}{|c|}{ RESULTS FOR HOLMIUM OXIDE MEASUREMENT } \\
\hline $\begin{array}{l}\text { Values } \\
\text { of wave- }\end{array}$ & $\begin{array}{c}\text { Spectral } \\
\text { slot }\end{array}$ & \multicolumn{14}{|c|}{ The corresponding wavelength T\% minimum (nm) } \\
\hline $\begin{array}{c}\text { Theoretical } \\
\text { values }\end{array}$ & \multirow{2}{*}{$2 \mathrm{~nm}$} & 241.10 & 250.00 & 278.10 & 287.50 & 333.50 & 345.40 & 361.10 & 385.80 & 416.60 & 451.30 & 467.90 & 485.20 & 536.90 & 640.80 \\
\hline $\begin{array}{c}\text { Measured } \\
\text { values }\end{array}$ & & 241.22 & 250.11 & 278.18 & 287.61 & 333.59 & 345.55 & 361.27 & 385.96 & 416.74 & 451.45 & 468.07 & 485.42 & 537.06 & 640.99 \\
\hline \multicolumn{2}{|c|}{ Confidence interval } & \multicolumn{14}{|c|}{$95 \%$ Confidence interval $\pm 1 \mathrm{~nm}$} \\
\hline
\end{tabular}

RESULTS FOR THE INTERMEDIARY VERIFICATION WITH TWO SOLUTIONS FORM THE CALIBRATION CURVE

\begin{tabular}{|c|c|c|c|c|c|c|}
\hline Result & \multicolumn{2}{|c|}{ Correct result } & \multicolumn{2}{c|}{ Acceptable result } & \multicolumn{2}{c|}{ Acceptable result } \\
\hline $\mathbf{x}$ & $\mathbf{x}-\mathbf{0 . 0 0 2 3 7 8}$ & $\mathbf{x}+\mathbf{0 . 0 0 2 3 7 8}$ & $\mathbf{x}-\mathbf{0 . 0 0 3 5 6 7}$ & $\mathbf{x}-\mathbf{0 . 0 0 2 3 7 8}$ & $\mathbf{x + \mathbf { 0 . 0 0 2 3 7 8 }}$ & $\mathbf{x}+\mathbf{0 . 0 0 3 5 6 7}$ \\
\hline 0.1697 & 0.1673 & 0.1721 & 0.1661 & 0.1673 & 0.1721 & 0.1733 \\
\hline $\mathbf{x}$ & $\mathbf{x}-\mathbf{0 . 0 0 1 8 6 6}$ & $\mathbf{x + 0 . 0 0 1 8 6 6}$ & $\mathbf{x}-\mathbf{0 . 0 0 2 7 9 9}$ & $\mathbf{x}-\mathbf{0 . 0 0 1 8 6 6}$ & $\mathbf{x}+\mathbf{0 . 0 0 1 8 6 6}$ & $\mathbf{x + 0 . 0 0 2 7 9 9}$ \\
\hline 0.7451 & 0.7432 & 0.747 & 0.7423 & 0.7432 & 0.747 & 0.7479 \\
\hline
\end{tabular}




\section{CONCLUSIONS}

A method for the determination of the free and hydrolysed formaldehyde from textile materials has been validated. The performance parameters (selectivity, limit of detection, limit of quantification, working range and method linearity, sensitivity, precision, recovery, robustness) of the method have been evaluated and they indicate that this method is precise and reliable. The method is accredited by RENAR, the Romanian Organism for the Accreditation of Laboratories.

\section{ACKNOWLEDGEMENTS}

This work was elaborated through Nucleu Program, conducted with $\mathrm{MCl}$ support, project no. 4N/2019/PN 191705 01 . The publication fee of the paper is funded by the Ministry of Research and Innovation within Program 1 Development of the national RD system, Subprogram 1.2 Institutional Performance - RDI excellence funding projects, Contract no. 6PFE/2018.

\section{REFERENCES}

[1] Kawakami, Y., Maruo, Y.Y., Nakagawa, T., Saito, H., A screening method for detecting formaldehyde emitted from textile products, In: Measurement: Journal of the International Measurement Confederation, 2015, 62, 41-46

[2] Schreier, T.M., Rach, J.J. \& Howe, G.E., Efficacy of formalin, hydrogen peroxide, and sodium chloride on fungalinfected rainbow trout eggs, In: Aquaculture, 1996, 140, 323-331

[3] Pietrzak, K., Otlewska, A., Danielewicz, D., Dybka, K., Pangallo, D., Kraková, L., Pu`skárová, A., Mária Bu`cková., Scholtz, V., Durovic, M., Surma-Slusarska, B., Demnerová, K., Gutarowska B., Disinfection of archival documents using thyme essential oil, silver nanoparticles misting and low temperature plasma, In: Journal of Cultural Heritage, 2017, 24, 69-77

[4] Gutarowska, B., Pietrzak, K., Machnowski, W., Milczarek, J.M., Historical textiles - a review of microbial deterioration analysis and disinfection methods, In: Textile Research Journal, 2017, 87, 2388-2406

[5] IARC Press Release 153, 2004, Available at: http://www.iarc.fr/ENG/Press_Releases/archives/pr153a.html [Accessed October 2019]

[6] NICNAS, Formaldehyde in Clothing and Textiles FactSheet, In: Australian National Industrial Chemicals Notification and Assessment Scheme, 2013

[7] Piccinini, P., Senaldi, C., Summa, C., European survey on the release of formaldehyde from textiles, Conducted within the CHEM TEST project on behalf of DG SANCO, 2007, ISBN 978-92-79-05215-6

[8] Sáenz, M., Alvarado, J., Pena-Pereira, F., Senra-Ferreiro, S., Lavilla, I., Bendicho, C., Liquid-phase microextraction with in-drop derivatization combined with microvolume fluorospectrometry for free and hydrolyzed formaldehyde determination in textile samples, In: Analytica Chimica Acta, 2011, 687, 50-55

[9] ISO 14184-1: 2011 Textiles - Determination of formaldehyde - Part 1: Free and hydrolysed formaldehyde (water extraction method)

[10] Decision no. 350/2014 laying down the ecological criteria for the award of the EU Ecolabel for textiles [notified with C(2014) 3677 number]; Celex number: 32014D0350, Published in Official Journal of the European Union no. 174 of 13.06 .2014

[11] Tanase, I.G., Pana, A., Radu, G. L., Buleandra, M., Validarea metodelor analitice, Ed. Printech, 2007

[12] ISO 11843, Capability of detection, Geneva (several parts)

[13] European Commission, Commission Decision 96/23/EC on measures to monitor certain substances and residues thereof in live animals and animal products and repealind Directives 85/258/EC and Decisions 89/187/EC and 91/664/EC, Off. J. Eur. Commun., 1, 125, 0010-0032, 23.05.1996

[14] ICH-Q2A, Guideline for Industry: Text on Validation of Analytical Procedures, 1995 Available at: http://www.fda.gov/ cder/guidance/index.htm [Accessed October 2019]

[15] Thompson, M., Ellison, S.L.R., Wood, R., Harmonized guidelines for single-laboratory validation of methods of analysis, In: Pure and Applied Chemistry, 2002, 74, 5, 835-855

Authors:

LUCIA OANA SECĂREANU ${ }^{1}$, CORNELIA-ELENA MITRAN ${ }^{1,2}$, IRINA-MARIANA SĂNDULACHE ${ }^{1,2}$, MIHAELA-CRISTINA LITE11,2, ELENA PERDUM ${ }^{1}$, OVIDIU-GEORGE IORDACHE ${ }^{1}$

${ }^{1}$ National Research and Development Institute for Textiles and Leather - INCDTP, Lucretiu Patrascanu Street, no. 16, 030508, Bucharest, Romanaia e-mail: office@incdtp.ro

2Politehnica University of Bucharest, 1-7 Gheorghe Polizu Street, 011061, Bucharest, Romania e-mail: secretariat@chimie.upb.ro

Corresponding author:

CORNELIA-ELENA MITRAN

e-mail: cornelia.mitran@incdtp.ro 